\title{
Investigation of an Elevational Gradient Reveals Strong Differences Between Bacterial and Eukaryotic Communities Coinhabiting Nepenthes Phytotelmata
}

\author{
Kadeem J. Gilbert ${ }^{1,2} \cdot$ Leonora S. Bittleston $^{1,3,4}$ (D) Mark Arcebal K. Naive ${ }^{5}$ (D) Anthony E. Kiszewski $^{6}$. \\ Perry Archival C. Buenavente ${ }^{7}$ (D) David J. Lohman ${ }^{7,8,9}$ (D) Naomi E. Pierce $^{1}$
}

Received: 19 November 2019 / Accepted: 25 February 2020 / Published online: 14 April 2020

(C) The Author(s) 2020

\begin{abstract}
Elevation is an important determinant of ecological community composition. It integrates several abiotic features and leads to strong, repeatable patterns of community structure, including changes in the abundance and richness of numerous taxa. However, the influence of elevational gradients on microbes is understudied relative to plants and animals. To compare the influence of elevation on multiple taxa simultaneously, we sampled phytotelm communities within a tropical pitcher plant (Nepenthes mindanaoensis) along a gradient from 400 to $1200 \mathrm{~m}$ a.s.l. We use a combination of metabarcoding and physical counts to assess diversity and richness of bacteria, micro-eukaryotes, and arthropods, and compare the effect of elevation on community structure to that of regulation by a number of plant factors. Patterns of community structure differed between bacteria and eukaryotes, despite their living together in the same aquatic microhabitats. Elevation influences community composition of eukaryotes to a significantly greater degree than it does bacteria. When examining pitcher characteristics, pitcher dimorphism has an effect on eukaryotes but not bacteria, while variation in $\mathrm{pH}$ levels strongly influences both taxa. Consistent with previous ecological studies, arthropod abundance in phytotelmata decreases with elevation, but some patterns of abundance differ between living inquilines and prey.
\end{abstract}

Keywords Arthropods $\cdot$ Bacteria $\cdot$ Elevational diversity gradients $\cdot$ Fungi $\cdot$ Phytotelmata $\cdot$ Protists

Electronic supplementary material The online version of this article (https://doi.org/10.1007/s00248-020-01503-y) contains supplementary material, which is available to authorized users.

Kadeem J. Gilbert

kjg5649@psu.edu

1 Department of Organismic and Evolutionary Biology, Harvard University, 26 Oxford St., Cambridge, MA 02138, USA

2 Department of Entomology, The Pennsylvania State University, 501 Agricultural Sciences and Industries Building, University Park, PA 16802, USA

3 Department of Civil and Environmental Engineering, Massachusetts Institute of Technology, 77 Massachusetts Avenue, Room 1-290, Cambridge, MA 02139, USA

4 Department of Biological Sciences, Boise State University, 1910 W University Dr, Boise, ID 83725, USA
5 Department of Biological Sciences, College of Science and Mathematics, Mindanao State University-Iligan Institute of Technology, Andres Bonifacio Ave, 9200 Iligan, Lanao del Norte, Philippines

6 Department of Natural and Applied Sciences, Bentley University, 175 Forest Street, Waltham, MA 02452, USA

7 Entomology Section, National Museum of Natural History, Manila, Philippines

8 Biology Department, City College of New York, City University of New York, New York, NY, USA

9 Ph.D. Program in Biology, Graduate Center, City University of New York, New York, NY, USA 


\section{Introduction}

Mountains, especially tropical mountains, can exhibit differences in climatic variables across their ranges comparable to the climatic changes that occur around the globe from equator to poles [1-4]. Because mountains create spatially compact environmental gradients, they are useful for exploring broad patterns across taxa. Decades of research has uncovered similar patterns across diverse taxa: whether monotonic or hump-shaped, plants, mammals, birds, amphibians, reptiles, insects, and other invertebrates all generally exhibit decreasing diversity and abundance with increasing elevation [5]. While studies of elevational gradients can be traced back to the time of Linnaeus, bacteria and other microbes have been the focus of such studies only recently-largely within the past decade [6]. The extent to which microbes follow the same macroecological trends established in plants and animals (macro-organisms or "macrobes") remains partially unresolved. One major line of thought on microbial macroecology is the Baas-Becking hypothesis: "everything is everywhere, and the environment selects", suggesting that bacteria are not dispersal-limited and thus not subject to the broad-scale spatial structuring seen in macrobes [7-12]. However, this view is controversial [13-17], and may not apply to eukaryotic microbes $[18,19]$.

Microbes have not been as extensively studied in the context of elevational gradients, but the past decade has seen an increasing number of studies examining elevational patterns of bacteria in soil $[6,8-12,20-22]$ and to a lesser extent, aquatic habitats [23-26]. Similar studies have also been conducted for fungi [27-35] and protists [18, 36-39]. Of these microbial elevational gradient studies, only a handful have compared diversity patterns of syntopic microbes and macrobes coinhabiting the same microhabitats. The results of these studies have also been inconsistent, with some finding that microbes and macrobes follow concordant patterns of richness (generally decreasing richness with increasing elevation) [6,22], and others finding that microbes and macrobes exhibit differing patterns $[21,25,40]$. Other, more general analyses have found that bacteria and micro-eukaryotes respond differently to environmental factors within the same habitats, with eukaryotes having stronger dispersal limitation [41-45]. It may thus be necessary to distinguish between bacteria and eukaryotes when comparing macrobes to microbes.

A multi-taxon comparative approach can contribute to improved understanding of elevational macroecology. Including organisms with diverse physiologies spanning multiple trophic levels helps improve the generalizability of observed patterns [46]. To achieve this task, our study utilizes communities in phytotelmata, which are small, specialized aquatic ecosystems contained within plant tissues such as tree holes or pitcher plants [47]. These systems have unique advantages for comparative multi-taxon studies: though small, they often encompass a diverse set of taxa, which can include bacteria, archaea, eukaryotic microbes, invertebrates, and vertebrates (the term "inquilines" has been used to refer to phytotelm inhabitants, especially invertebrates) [47]. Thus, they serve as convenient, replicated communities with distinct boundaries in which multiple taxa experience a similar environment and can be compared simultaneously using a metabarcoding approach [48]. Specifically, we studied tropical pitcher plants (genus Nepenthes), which are carnivorous plants with modified leaves or "pitchers." These pitchers act as pitfall traps, in which a secreted fluid pool digests captured insects, while also serving as a phytotelm habitat $[49,50]$. Trait variation in pitchers, both morphological and physiological, can also influence community composition. Morphological features include pitcher dimorphism (an individual plant produces two distinct pitcher morphs, "lower" and "upper" pitchers from the terrestrial rosette and arboreal climbing phases, respectively) and variation in red pigmentation [51,52]. Coloration may affect visual signaling to arthropods [52, 53]. Pitcher dimorphism may involve differences in visual and olfactory signaling modalities in addition to the terrestrial/arboreal microhabitat distinction [54, 55]; two studies found between-morph differences in inquiline insect community composition [56, 57]. One key physiological feature of pitchers is their active regulation of fluid $\mathrm{pH}$ levels [58], which can vary significantly within or between species $[59,60]$. Nepenthes phytotelm communities typically include bacteria, fungi, algae, protozoans, mites, and aquatic insect larvae [47, 49, 59], and, occasionally, anuran tadpoles [61-63] and crabs [64]. Previous metabarcoding studies show that their communities are specialized and distinct from the surrounding environment [65], which can be attributed to the specific conditions within the plants such as the acidic $\mathrm{pH}$ levels of the fluids $[65,66]$.

In this study, we examine phytotelm communities of Nepenthes mindanaoensis along a 400-1200 m a.s.1. elevational gradient on Mt. Hamiguitan, Mindanao, Philippines. We collected the entire fluid contents and used a DNA metabarcoding approach to sequence $16 \mathrm{~S}$ and $18 \mathrm{~S}$ rRNA genes to capture the community-level diversity of bacteria and eukaryotes, respectively. The sequence-based approach captures both micro- and macro-eukaryotes (i.e., metazoans). We also identified and counted physical specimens of arthropods in the pitcher, both the inquilines (generally aquatic insect larvae that complete their development living and feeding inside the pitcher fluids), as well as the partially digested prey remains. Our primary goal was to determine whether pitcher phytotelm communities are structured by elevation, or whether plant-regulated factors such as $\mathrm{pH}$ and morphology have a greater effect that overrides the effect of elevation (which might be largely generated by external climatic factors such as temperature and precipitation). We were also interested in whether the relative effects of external gradients differed among taxa. We did not attempt to establish the 
effect of specific climatic factors, and unfortunately elevation and geographic distance covaried in our transect, so it was not statistically possible to disentangle the effects of these separate external (i.e., non-plant-regulated) factors on pitcher biota. However, we still gain insight into the relative influence of plant-regulated versus external factors. Whether the influence of the external gradient is due to climate or distance (or a combination of both), determining its relative effect on different taxa provides information of interest, since the comparative effect of geographic distance on microbes and macrobes is also an open question $[42,67]$.

\section{Methods}

\section{Site}

Mount Hamiguitan (N 06 43' 1.81", E $126^{\circ} 10^{\prime} 24.35^{\prime \prime}$ ) is located in the southernmost peninsula of eastern Mindanao, the southernmost major island of the Philippines. Much like the neighboring Indo-Australian Archipelago, the Philippines is a hotbed of biodiversity. Because the majority of its islands were never connected to mainland Southeast Asia, the Philippines boasts impressive levels of endemism: an estimated $45 \%$ of vertebrate species, $50 \%$ of plant species, and $70 \%$ of insect species are endemic [68]. Further, many species are endemic to single islands or even single peaks. Five Nepenthes species are endemic to Mt. Hamiguitan [69, 70]. This site-level endemism is one reason for Mt. Hamiguitan Range Wildlife Sanctuary's designation as an UNESCO World Heritage Site. The site ranges from 75 to $1637 \mathrm{~m}$ a.s.l. and has several habitat types, including dipterocarp forest, montane forest, moss forest, and pygmy moss forest at the highest elevation.

Following the general pattern observed on tropical mountains, there is a pronounced gradient in both temperature and precipitation. We determined the site's climatic properties using data from WorldClim [71], analyzed using the "st" package in R [72], with a resolution of $5 \mathrm{~min}$ for max temperature and $2.5 \mathrm{~min}$ for all other variables. In any given month, the mean temperature for the lowest elevation region of Mt. Hamiguitan is $26-27^{\circ} \mathrm{C}$ compared to $21-22^{\circ} \mathrm{C}$ at the highest elevation, while the monthly minimum temperature ranges from 21 to $22{ }^{\circ} \mathrm{C}$ at the lowest elevation and $16-18{ }^{\circ} \mathrm{C}$ at the highest elevation. For maximum temperature, the range is 30 $30.5{ }^{\circ} \mathrm{C}$ at low elevation and $27.5-29{ }^{\circ} \mathrm{C}$ at high elevation. Precipitation patterns are more variable throughout the year than temperature patterns, but during the months of June to September (monsoon season), conditions tend to be wetter at low elevation: $18-36 \mathrm{~mm}$ at the lowest elevation compared to $17-24 \mathrm{~mm}$ at the highest elevation (Supplementary Table 1).

\section{Sample Collection}

Sampling was conducted $14-17$ July 2016 . We worked along a transect from $\sim 400$ to $\sim 1200 \mathrm{~m}$ a.s.l. (a Euclidian distance of $\sim 4.2 \mathrm{~km}$, Fig. 1). Nepenthes mindanaoensis individuals were abundant throughout this transect, allowing for systematic sampling; however, we sampled fewer pitchers from $\sim 600$ to $800 \mathrm{~m}$ a.s.l. due to more challenging terrain. We collected the contents of 33 $N$. mindanaoensis pitchers (Table 1), selecting only a single healthy mature pitcher per individual plant. We poured the entire fluid contents from each pitcher directly into a single, sterile $50 \mathrm{~mL}$ Falcon tube, sealing the capped tubes with parafilm to safeguard against spillage or contamination prior to the addition of preservative. The tubes were kept secure and out of the sun within a backpack during in-field transit. We added $1 \mathrm{~mL}$ of cetyl trimethylammonium bromide (CTAB) buffer for every $1 \mathrm{~mL}$ of pitcher fluid within $24 \mathrm{~h}$ of collection as a preservative (this was done indoors at a field station) [65]. Prior to the addition of CTAB, we recorded the volume of each sample and removed a small amount of liquid to measure $\mathrm{pH}$ with ColorPhast $\mathrm{pH}$ strips (Merck KGaA Darmstadt, Germany). We measured the length (distance from the base of the pitcher to the insertion of its lid) and width (the diameter of the widest section of the pitcher) of each pitcher in situ using digital calipers. We also recorded pitcher morph (upper or lower) and color (primarily green or red-pigmented) of each sample. We estimated "canopy openness" for each pitcher by photographing the sky above from pitcher's-eye-view using a pointand-shoot digital camera (Canon PowerShot ELPH 170IS, which has a $4.5-54 \mathrm{~mm}$ zoom lens with $12 \times$ digital zoom) and calculating the area not covered by vegetation using Image J [73]; this metric does not only include leaf area of canopy trees but also all herbaceous layers shading that pitcher. We obtained GPS coordinates and elevation of each sampled pitcher using a Garmin eTrex handheld GPS unit. We determined Euclidian distance between plants using the distance tool in Google Earth Pro.

\section{Arthropod Identification and Analysis}

After removing fluid for DNA extraction, we filtered arthropod bodies and debris from fluid samples using fine gauze $(<$ $0.5 \mathrm{~mm}$ pore size) and separated taxa under a dissecting microscope. We created high-resolution digital images using a digital camera mounted on a dissecting microscope together with the AutoMontage photo compositing system, then stored the specimens in $100 \%$ ethanol. We counted total arthropod numbers from each pitcher. For arthropods classed as insect prey, numbers were based on a combination of head capsule counts and wing counts; in the case of wings, we counted two 

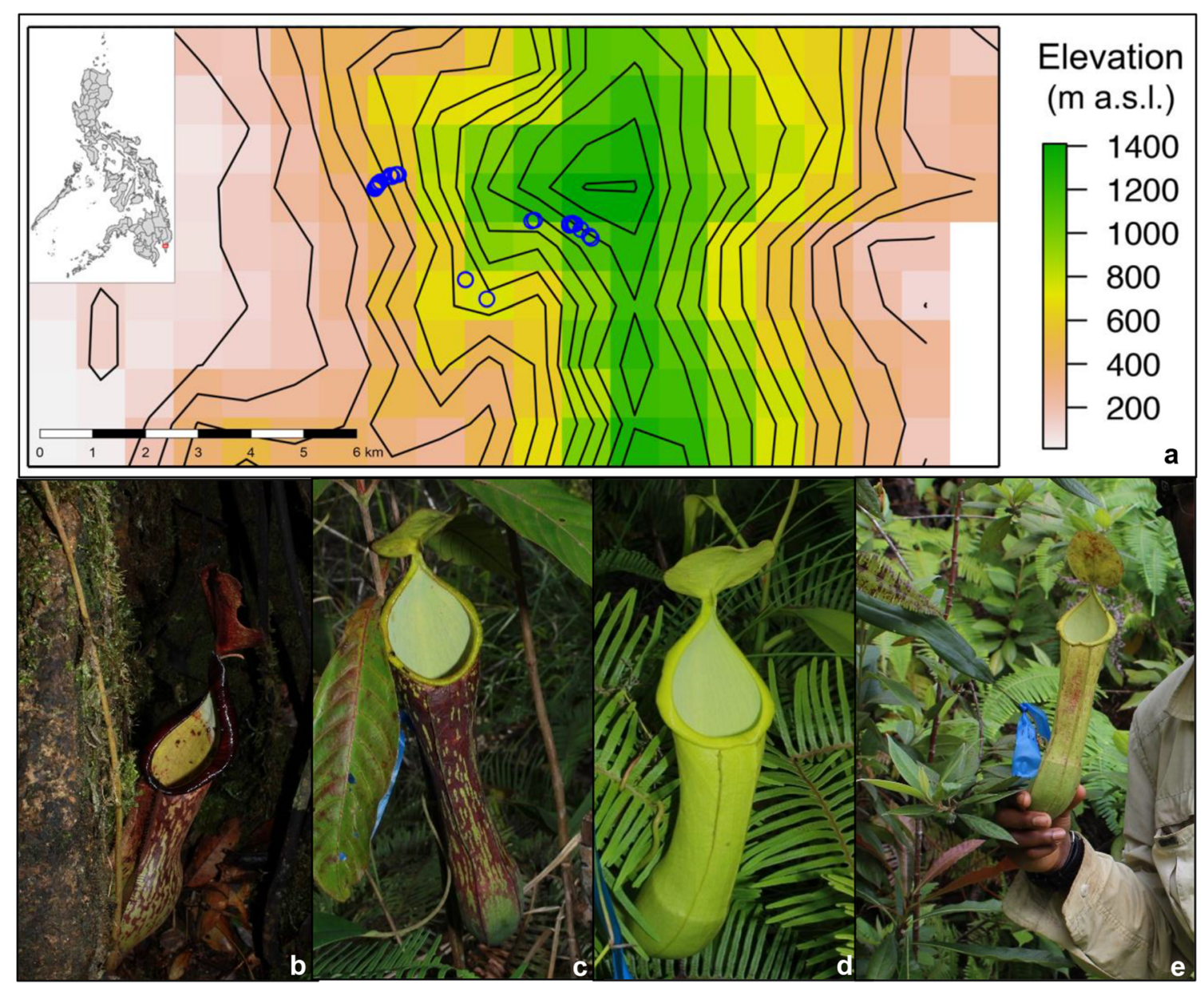

Fig. 1 a Sampling area for the study, blue circles indicate the locations of the sampled pitchers on Mount Hamiguitan. Location of the area within the Philippines is indicated by a red box in the inset. $\mathbf{b}-\mathbf{e}$ Representative

morphologically similar wings as one individual. Arthropod counts were categorized as culicid (mosquito) larvae, ceratopogonid (midge) larvae, brachyceran (a dipteran suborder) larvae, mites (Acari), ants (Formicidae), and other insect prey. We used field guides to key ants to species where possible [74], and culicids to genus [75]. Order-level designation of insect prey was based on wing venation patterns or the appearance of head capsules. For further statistical analysis, both arthropod abundance (number of individual arthropods within a taxonomic category) and richness (number of taxa within a category, morphospecies in the case of ants and culicids, or orders in the case of non-ant insect prey) were based on physical counts, rather than $18 \mathrm{~S}$ sequences.

\section{Extraction and Sequencing}

We used metabarcoding to sequence the $16 \mathrm{~S}$ and $18 \mathrm{~S}$ ribosomal RNA genes in the fluid to represent the entire prokaryotic and eukaryotic communities in the pitcher fluid. DNA was extracted using a bead-beating and phenol-chloroflorm extraction method after concentrating the cells with a photographs of $N$. mindanaoensis pitchers sampled in this study: lower pitcher (b) and upper pitchers (c-e). Photos: MAKN

centrifuge [76]. Negative controls were included for each set of extractions, and no measurable DNA was recovered from them. Amplicons were generated and sequenced at the Environmental Sample Preparation and Sequencing Facility (ESPSF) at Argonne National Laboratory. We targeted the $\mathrm{V} 4$ region of the $16 \mathrm{~S}$ rRNA gene using primers $515 \mathrm{~F}-806 \mathrm{R}$ $[77,78]$ and the $\mathrm{V} 9$ region of the $18 \mathrm{~S}$ genes using primers Euk1391f-EukBr [79, 80]. Sequences were assembled and assigned to operational taxonomic units (OTUs) using the QIIME pipeline and Harvard's Odyssey computer cluster [65]. We used the Greengenes and SILVA databases for 16S and $18 \mathrm{~S}$ sequences, respectively, for taxonomic classification of OTUs, with a cutoff of $97 \%$ sequence identity. In some cases, further taxonomic assignment was determined using NCBI BLAST. Neighbor-joining phylogenies were constructed for all bacterial (16S) and eukaryotic (18S) OTUs. 16S OTUs classified as chloroplast and mitochondrial sequences, and 18S OTUs classified as Embryophyta (land plant) sequences were removed from downstream analyses of community similarity to avoid inclusion of possible contaminants from host plant cells. 
Table 1 List of all Nepenthes mindanaoensis pitcher fluid samples collected, with data on pitcher morph, elevation, and Euclidean distance from start of transect

\begin{tabular}{|c|c|c|c|}
\hline Pitcher ID & Morph & Elevation (m a.s.1) & Euclidean distance from start $(\mathrm{m})$ \\
\hline MIN001 & Upper & 446 & 0 \\
\hline MIN002 & Upper & 447 & 6.89 \\
\hline MIN003 & Upper & 451 & 28.21 \\
\hline MIN004 & Upper & 446 & 28.21 \\
\hline MIN005 & Upper & 458 & 59.39 \\
\hline MIN006 & Lower & 459 & 72.61 \\
\hline MIN007 & Lower & 468 & 88.05 \\
\hline MIN009 & Upper & 465 & 102.25 \\
\hline MIN008 & Lower & 464 & 106.06 \\
\hline MIN010 & Upper & 464 & 108.02 \\
\hline MIN011 & Upper & 471 & 110.66 \\
\hline MIN012 & Upper & 475 & 154.95 \\
\hline MIN013 & Upper & 506 & 368.83 \\
\hline MIN014 & Upper & 514 & 385.3 \\
\hline MIN015 & Upper & 525 & 455.97 \\
\hline MIN016 & Lower & 523 & 462.43 \\
\hline MIN017 & Upper & 533 & 476.6 \\
\hline MIN018 & Lower & 533 & 490.63 \\
\hline MIN019 & Upper & 533 & 499.06 \\
\hline MIN020 & Upper & 539 & 511.12 \\
\hline MIN022 & Upper & 791 & 2249.2 \\
\hline MIN021 & Upper & 791 & 2253.75 \\
\hline MIN035 & Upper & 837 & 2755.37 \\
\hline MIN023 & Lower & 1003 & 3082.09 \\
\hline MIN024 & Lower & 1008 & 3107.74 \\
\hline MIN026 & Lower & 1042 & 3763.74 \\
\hline MIN025 & Lower & 1054 & 3776.82 \\
\hline MIN027 & Lower & 1087 & 3822.08 \\
\hline MIN028 & Lower & 1120 & 3870.16 \\
\hline MIN029 & Lower & 1112 & 3884.43 \\
\hline MIN030 & Upper & 1111 & 3884.43 \\
\hline MIN034 & Lower & 1202 & 4214.95 \\
\hline MIN033 & Lower & 1200 & 4248.15 \\
\hline
\end{tabular}

\section{Statistical Analysis}

All analyses were conducted in $\mathrm{R}$ version 3.5.0. We first conducted a principal components analysis (PCA) of all recorded sample traits (elevation, Euclidian distance, fluid $\mathrm{pH}$, canopy openness, fluid volume, pitcher length, pitcher width, pitcher morph, and pitcher color) in order to determine the axes of variation and assess correlation among traits. Based on this assessment, we determined that Euclidian distance (the shortest distance between two sampling points) was strongly, positively correlated with elevation (on the same PCA axis), and thus did not include Euclidian distance as a variable in our analyses. In order to further probe the effect of physical Euclidian distance on our data, we plotted the log of the Unifrac distance matrix for bacteria or eukaryotes against the log of Euclidian distance (in meters) to search for distance-decay patterns. One would expect to see stronger distance-decay patterns in more dispersal-limited taxa [81, 82]. In addition, we used the function "betadisper," together with "permutest" to calculate and compare levels of 16S-/18S-based beta diversity (pitcher-to-pitcher turnover) between low $(<700 \mathrm{~m}$ a.s.1.) and high (> $700 \mathrm{~m}$ a.s.1.) elevation pitchers for bacteria and eukaryotes. Since high elevation pitchers were more widely distributed in the habitat than low elevation pitchers (maximum Euclidian distance of $1998.95 \mathrm{~m}$ vs. $511.25 \mathrm{~m}$, respectively), we expected greater turnover at high elevations if inter-pitcher community similarity were strongly influenced by Euclidian distance. We chose to use pitcher length as the sole pitcher dimension because 
pitcher length is positively correlated with width, but unlike pitcher width, length is not correlated with fluid volume.

We analyzed $16 \mathrm{~S} / 18 \mathrm{~S}-$ based community composition with the "vegan" R package, using the non-metric multidimensional scaling (NMDS) ordination method and the unweighted Unifrac distance metric. Samples were rarefied to 1311 (16S) and 1103 (18S) sequences. We assessed the significance of clustering by categorical variables (pitcher morph and color) using the "adonis" function in the "vegan" package [83], which performs a PERMANOVA test. For quantitative traits (elevation, $\mathrm{pH}$, canopy openness, fluid volume, pitcher length), we performed Mantel tests. We calculated alpha diversity according to "effective number of species" [84], which can be interpreted as a direct measure of species richness, unlike standard diversity indices. We calculated effective number of species for $16 \mathrm{~S} / 18 \mathrm{~S}$ data from Shannon Index values obtained using the function "diversity" in the "vegan" package.

To examine patterns of differential abundance of individual OTUs in relation to fluid properties, we performed the analysis of composition of microbiomes (ANCOM) [85], a test designed to examine taxon abundance while accounting for the fact that metagenomics studies yield relative abundance data as opposed to absolute abundance. For ANCOM tests, we used the full set of successfully extracted samples, only included OTUs with sequence counts above 100, and corrected for multiple testing (FDR) at a significance level of 0.05 . Continuous environmental variables were transformed into categorical variables for ANCOM tests. We binned $\mathrm{pH}$ into three categories: low $(\leq 3.0)$, mid $(3.0-4.5)$, and high $(\geq 5.0)$. Elevation was binned into three categories: low $(400-600 \mathrm{~m}$ a.s.1.), mid (600-900 $\mathrm{m}$ a.s.1.), and high (>900 $\mathrm{m}$ a.s.1.). Canopy openness was binned into three categories, which generally correspond to our preliminary qualitative assessments of canopy openness in the field: closed $(\sim 0-20 \%$ open), semi-open ( $\sim 20-40 \%$ open), and open $(\sim 40-100 \%$ open).

In order to assess correlations of our measures with physical specimen-based arthropod counts, we conducted Poisson regressions using the "glm" function in the "lme4" package in $\mathrm{R}$. We included all examined factors (elevation, $\mathrm{pH}$, canopy openness, fluid volume, pitcher length, pitcher morph, and pitcher color) together into a single generalized linear model (Poisson regression), in order to account for correlations between factors. We conducted a separate regression each for the abundance of culicids, ceratopogonids, brachyceran larvae, mites, ants, and other insect prey and applied a Bonferroni correction in assessing significance for the family-wise set of six arthropod groups. The same method was used to assess correlations with richness for the family-wise set of three arthropod groups: ant morphospecies, culicid morphospecies, and non-ant insect prey orders.

\section{Results}

\section{Factors Structuring Community Composition}

Fluid $\mathrm{pH}$ is the only factor significantly structuring bacterial community composition (Mantel $r=0.64, p=0.001$; Table 2). While not significant at the Bonferroni-corrected alpha level of 0.007 , bacteria appear to be somewhat structured by elevation as well, though to a lesser degree than $\mathrm{pH}$ (Mantel $r=$ $0.22, p=0.009$ ). For eukaryotes, both elevation (Mantel $r=$ $0.40, p=0.002$ ) and $\mathrm{pH}$ (Mantel $r=0.31, p=0.004$ ) have a significant effect on community composition, with elevation having a somewhat stronger effect. However, when Metazoa are excluded from the OTU table, elevation is the only factor with a significant effect (Mantel $r=0.35, p=0.001$ ). In this case, $\mathrm{pH}$ shows a possible effect though not significant (Mantel $r=0.31, p=0.015$; Table 2).

\section{OTU Taxonomic Composition}

We found a total of 2867 bacterial and 923 eukaryotic (including 405 metazoan) operational taxonomic units (OTUs), analogous to species. Proteobacteria-particularly Acetobacteraceae in Alphaproteobacteria, Burkholderiales in Betaproteobacteria, and Enterobacteriales in Gammaproteobacteria - dominate the bacterial composition (comprising on average $82 \%$ of all sequences); Actinobacteria, Bacteroidetes, and Firmicutes are also common across samples, with lower relative abundance (comprising on average $11 \%, 1.9 \%$, and $1.2 \%$ of all sequences, respectively; Fig. 2). The eukaryotic communities consist of many taxa, including Metazoa, Alveolata, Stramenopiles (especially Chrysophyceae), Rhizaria, Cryptophyceae (especially Goniomonas), Discoba (primarily euglenids), Fungi, and Amoebozoa. Within Metazoa, Insecta is dominant (comprising on average $86 \%$ of all metazoan sequences), followed by Arachnida (specifically mites in Acari; $4.3 \%$ of sequences). Other arthropods and nematodes appear far less frequently and with lower relative abundance (Fig. 2). We observed frog eggs (from an unidentified rhacophorid) in one of the pitchers we sampled, and the $18 \mathrm{~S}$ data was able to capture this (Fig. 2).

\section{Sequence-Based Alpha Diversity}

Bacterial 16S-based alpha diversity ("effective number of species", Jost [68]) does not significantly correlate with elevation (Table 3, glm, $t$ value $=0.646, p=0.526$ ). The only factor that significantly correlates with bacterial alpha diversity is $\mathrm{pH}$, with greater alpha diversity at higher $\mathrm{pH}(\mathrm{glm}, t$ value $=$ $3.401, p=0.003$ ). Eukaryotic 18S-based alpha diversity also does not significantly correlate with elevation (Table 3, glm, $t$ value $=-0.283, p=0.780$ ). Neither does it significantly correlate with $\mathrm{pH}(\mathrm{glm}, t$ value $=1.256, p=0.225)$. The only 
Table 2 Results of Mantel $\left({ }^{1}\right)$ or PERMANOVA $\left({ }^{2}\right)$ analyses of 16S- or $18 \mathrm{~S}$-based community composition for Bacteria, Eukaryotes, and Eukaryotes without Metazoa. The seven factors constitute separate tests on the same ordination for each of the respective three taxa, so the set of tests for each taxon is accordingly considered a family-wise set to account for multiple testing. "Coefficient" refers either to Mantel $r$ or PERMANOVA $R^{2}$ depending on the test

\begin{tabular}{|c|c|c|c|c|c|c|}
\hline \multirow[t]{2}{*}{ Factor } & \multicolumn{2}{|l|}{ Bacteria } & \multicolumn{2}{|l|}{ Eukaryotes } & \multicolumn{2}{|c|}{ Eukaryotes without Metazoa } \\
\hline & Coefficient & $p$ value & Coefficient & $\mathrm{p}$ value & Coefficient & $\mathrm{p}$ value \\
\hline Elevation $^{1}$ & 0.220 & 0.009 & 0.400 & $0.002 *$ & 0.351 & $0.001 *$ \\
\hline $\mathrm{pH}^{1}$ & 0.640 & $0.001 *$ & 0.310 & $0.004 *$ & 0.300 & 0.015 \\
\hline Canopy openness ${ }^{1}$ & 0.020 & 0.350 & 0.070 & 0.130 & 0.020 & 0.399 \\
\hline Fluid volume $^{1}$ & 0.060 & 0.280 & 0.060 & 0.280 & 0.023 & 0.397 \\
\hline Pitcher length $^{1}$ & 0.002 & 0.468 & -0.050 & 0.700 & -0.095 & 0.803 \\
\hline Pitcher morph $^{2}$ & 0.060 & 0.020 & 0.080 & 0.016 & 0.066 & 0.216 \\
\hline Pitcher color ${ }^{2}$ & 0.030 & 0.910 & 0.039 & 0.572 & 0.050 & 0.586 \\
\hline
\end{tabular}

*Indicates significance at Bonferroni-corrected alpha level of 0.007

factor that significantly correlates with eukaryotic alpha diversity is pitcher morph, with greater alpha diversity in lower pitchers $(\mathrm{glm}, t$ value $=-3.007, p=0.007)$. When Metazoa are removed from the eukaryotic OTU table, no factor significantly correlates with alpha diversity (Table 3). Bacterial and eukaryotic alpha diversity do not clearly correlate with one another (linear model, $R^{2}=0.11, p=0.09$ ) unless metazoans are removed from the eukaryotic OTU table (linear model, $R^{2}=0.28, p=0.006$ ), in which case non-metazoan eukaryotic alpha diversity positively correlates with bacterial alpha diversity.

\section{Relative Abundance of Individual OTUs-ANCOM Tests}

The relative abundance of one bacterial OTU and one eukaryotic OTU varied significantly with elevation. The bacterial OTU is assigned to Acetobacteraceae (unclassified to genus); this OTU appears at low elevation, but not at mid or high. However, this trend is not representative of Acetobacteraceae in general, which show no differences in relative abundance across elevation categories (Kruskal-Wallis $\chi^{2}=4.836, p=$ 0.089). The eukaryotic OTU is assigned to Chrysophyceae (Stramenopiles, "uncultured marine eukaryote E222") and is present at mid and high elevation, but not at low. This reflects the trend in Stramenopiles in general, as all Stramenopile OTUs together are much less abundant at low elevation than mid and high elevation (Kruskal-Wallis $\chi^{2}=20.84, p<0.0001$ ). While no Cryptophyceae OTUs were determined to be differentially abundant by elevation through the ANCOM test, Cryptophyceae in general (all classified as the genus Goniomonas) tend to be more abundant at low elevation, in contrast to the Chrysophyceae (Kruskal-Wallis $\chi^{2}=6.561$, $p=0.038$; Fig. 3a).

The relative abundances of two bacterial OTUs and one eukaryotic OTU were significantly differentially abundant across $\mathrm{pH}$ categories. The bacterial OTUs include one classified in the genus Acidisoma and one in Acidocella (both Acetobacteraceae), which both tended to decrease with increasing $\mathrm{pH}$. This trend reflects what can be seen for all Acetobacteraceae, with lower mean log relative abundance in the high $\mathrm{pH}$ category (Kruskal-Wallis $\chi^{2}=11.663, p=$ 0.003 , Fig. 3b). As Acetobacteraceae are the dominant representatives of Alphaproteobacteria, the trend also holds for Alphaproteobacteria in general (though not statistically significant, Kruskal-Wallis $\left.\chi^{2}=5.329, p=0.07\right)$. This can be contrasted with Betaproteobacteria, which have higher mean $\log$ relative abundance at higher $\mathrm{pH}$ (Kruskal-Wallis $\chi^{2}=$ 10.327, $p=0.006$ ), or Gammaproteobacteria which exhibit no pronounced trend with $\mathrm{pH}$ (Kruskal-Wallis $\chi^{2}=3.516$, $p=0.172$; Fig. 3c).

The single eukaryotic OTU with significant differential abundance across $\mathrm{pH}$ categories was classified as belonging to Termitomyces (Agaricomycotina: Basidiomycota); the trend of higher relative abundance at high $\mathrm{pH}$ compared to low and mid pH categories is generalizable to Agaricomycotina (Kruskal-Wallis $\chi^{2}=10.669, p=0.005$ ). This can be contrasted with Saccharomycetes (Ascomycota) which have lower relative abundance at high $\mathrm{pH}$ compared to low and mid $\mathrm{pH}$ categories (Kruskal-Wallis $\chi^{2}=11.697, p=$ 0.003, Fig. 3d).

\section{Correlations Among Factors-Elevation and Euclidian Distance}

The seven continuously varying factors we recorded (elevation, Euclidian distance, canopy openness, $\mathrm{pH}$, fluid volume, and pitcher length/width) differed considerably among our sampled pitchers (Fig. 4), with $68 \%$ of the total variation explained by PCA axes 1 and 2. As previously noted, elevation and Euclidian distance strongly covary. We did not find a distance-decay relationship for either bacteria or eukaryotes; 

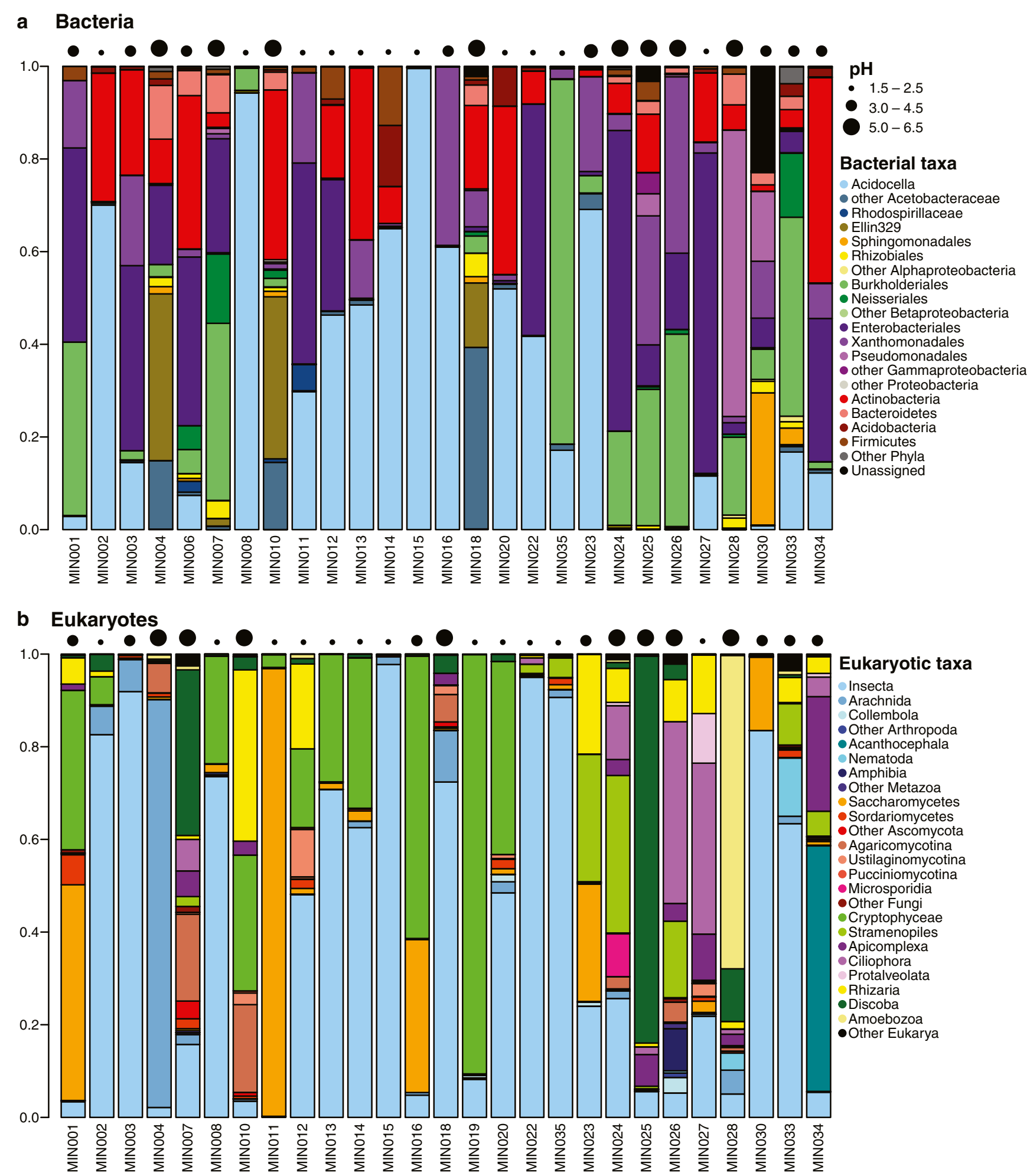

Fig. 2 Stacked barplots showing relative abundances (sequence-based) of bacterial taxa (a) and eukaryotic taxa (b) as determined by 16S and 18S metabarcoding, respectively. Samples arranged by increasing elevation. The fluid $\mathrm{pH}$ of the samples is indicated by proportionally sized circles

rather, there is a slight positive correlation between community similarity and Euclidian distance for bacteria $\left(R^{2}=0.012, p=\right.$ $0.038)$, eukaryotes $\left(R^{2}=0.077, p<0.0001\right)$, and eukaryotes without Metazoa $\left(R^{2}=0.061, p<0.0001\right)$. Bacteria show no significant difference in beta diversity (pitcher-to-pitcher turnover) between low elevation (average distance to median $=$ 0.52 ) and high elevation (average distance to median $=0.51$ ) in our analysis (permutation test for homogeneity of 
Table 3 Results of generalized linear model test of factors correlating with 16S- or 18S-based alpha diversity ("effective number of species", Jost 2006). All factors included in one model to account for correlations between factors

\begin{tabular}{|c|c|c|c|c|c|c|}
\hline \multirow[t]{2}{*}{ Factor } & \multicolumn{2}{|l|}{ Bacteria } & \multicolumn{2}{|c|}{ Eukaryotes } & \multicolumn{2}{|c|}{ Eukaryotes without Metazoa } \\
\hline & $t$ value & $p$ value & $t$ value & $p$ value & $t$ value & $p$ value \\
\hline Elevation & 0.646 & 0.526 & -0.283 & 0.780 & 1.349 & 0.193 \\
\hline $\mathrm{pH}$ & 3.401 & $0.003 *$ & 1.256 & 0.225 & 1.224 & 0.236 \\
\hline Canopy openness & 0.238 & 0.815 & -1.182 & 0.252 & 0.273 & 0.788 \\
\hline Fluid volume & -0.651 & 0.523 & 1.132 & 0.272 & 0.234 & 0.818 \\
\hline Pitcher length & 0.543 & 0.594 & 1.492 & 0.152 & 0.848 & 0.407 \\
\hline Pitcher morph (uppers relative to lowers) & -0.534 & 0.599 & -3.007 & $0.007 *$ & -1.63 & 0.120 \\
\hline Pitcher color (red relative to green) & -0.795 & 0.437 & -1.373 & 0.186 & -1.351 & 0.192 \\
\hline
\end{tabular}

*Significant at a Bonferroni-corrected alpha level of 0.0167

dispersions, $F=0.27, p=0.59$ ). Eukaryotes also show no significant difference in beta diversity between low (average distance to median $=0.462$ ) and high (average distance to median $=0.457$ ) elevation (permutation test for homogeneity of dispersions, $F=0.04, p=0.85$ ). Without Metazoa, eukaryotes still show no significant difference in beta diversity between low (average distance to median $=0.441$ ) and high (average distance to median $=0.447$ ) elevation (permutation test for homogeneity of dispersions, $F=0.04, p=0.85$ ). The lack of distance-decay patterns or change in beta diversity with elevation suggests that pitcher organisms are not dispersal limited across this transect.

\section{Community Composition, Richness, and Abundance of Arthropods-Physical Counts}

We examined physical specimens of inquiline and prey arthropods to obtain count data. Physical count data differ from $18 \mathrm{~S}$ sequence data. For instance, we did not obtain any OTUs assigned as ants, despite ants making up the majority of prey items we observed; this has previously occurred in Nepenthes metabarcoding studies [86] and may reflect primer biases against Formicidae. Unlike a previous study [86], OTU sequence counts in our study do not correlate well with physical specimen counts (linear regressions on log-transformed data, culicids: $R^{2}=0.04$, $p=0.31$; ceratopogonids: $R^{2}=0.005, p=0.74$; mites: $R^{2}=$ $0.001, p=0.88$; non-ant insect prey: $\left.R^{2}=0.006, p=0.69\right)$. On the other hand, $18 \mathrm{~S}$ data seem to accurately capture the presence of nematoceran (i.e., most inquiline dipterans) families and nonant insect prey orders observed from physical specimens across fluid samples (Supplementary Fig. 1). Unless otherwise noted, all analyses of arthropod composition, richness, and abundance henceforth are based on physical specimen counts.

Most of the insect inquilines that we identified were mosquito larvae (Culicidae, 772 individuals), followed by midges (Ceratopogonidae, 69 individuals), and a few individuals belonging to the sub-order Brachycera (possibly representatives of the family Phoridae, 13 individuals). All of the culicid larvae in our samples were identified as the genus Tripteroides, which we classified into four distinct morphospecies based on characteristics of spines and setae (Supplementary Fig. 2). Mites in the family Histiostomatidae are known Nepenthes inquilines [87] and our 18S data revealed their presence (94\% of mite OTU sequence counts), but the only mites we could see were in a different lineage: the order Oribatida. This is likely because oribatids are relatively large-bodied and pigmented, while histiostomatids are generally smaller and transparent, and thus more likely to be overlooked or lost when being filtered from the pitcher fluid. We are uncertain whether the oribatid mites function as inquilines or prey, though the latter appears more likely given their lack of obvious aquatic adaptations compared to Histiostomatidae [88]. The prey spectrum is dominated by ants; there were a total of 1172 ants across all samples (mean \pm standard deviation $=75.4 \pm 35.5$ ) compared to a total of 122 prey items identified as other insects (mean \pm standard deviation $=3.70 \pm 4.16$ ). We identified 42 morphospecies of ants (3 identifiable to named species) in 5 subfamilies and 15 genera (Supplementary Table 2). The non-ant prey included insects from 11 different orders (Supplementary Table 3). Even after ants were removed, Hymenoptera (primarily Chalcidoidea) was the most frequently encountered order (18 samples), followed by Diptera (13 samples), Coleoptera (12 samples), and Hemiptera (10 samples); the remaining orders each occurred in four or fewer pitchers.

Morphospecies-level richness of culicids, ants, and ordinal richness of non-ant insect prey was not significantly correlated with elevation (Table $4, p>0.05$ in all cases). There were no significant effects of the other measured factors on richness (Table $4, p>0.05$ for ants and non-ant insect prey), except that culicid morphospecies-level richness increases with decreasing $\mathrm{pH}$ (glm, $z$ value $=-2.89, p=0.004)$.

Culicids, mites, and ants were significantly less abundant at high elevations (Table 5, $p<0.001$ in all cases). Brachyceran 

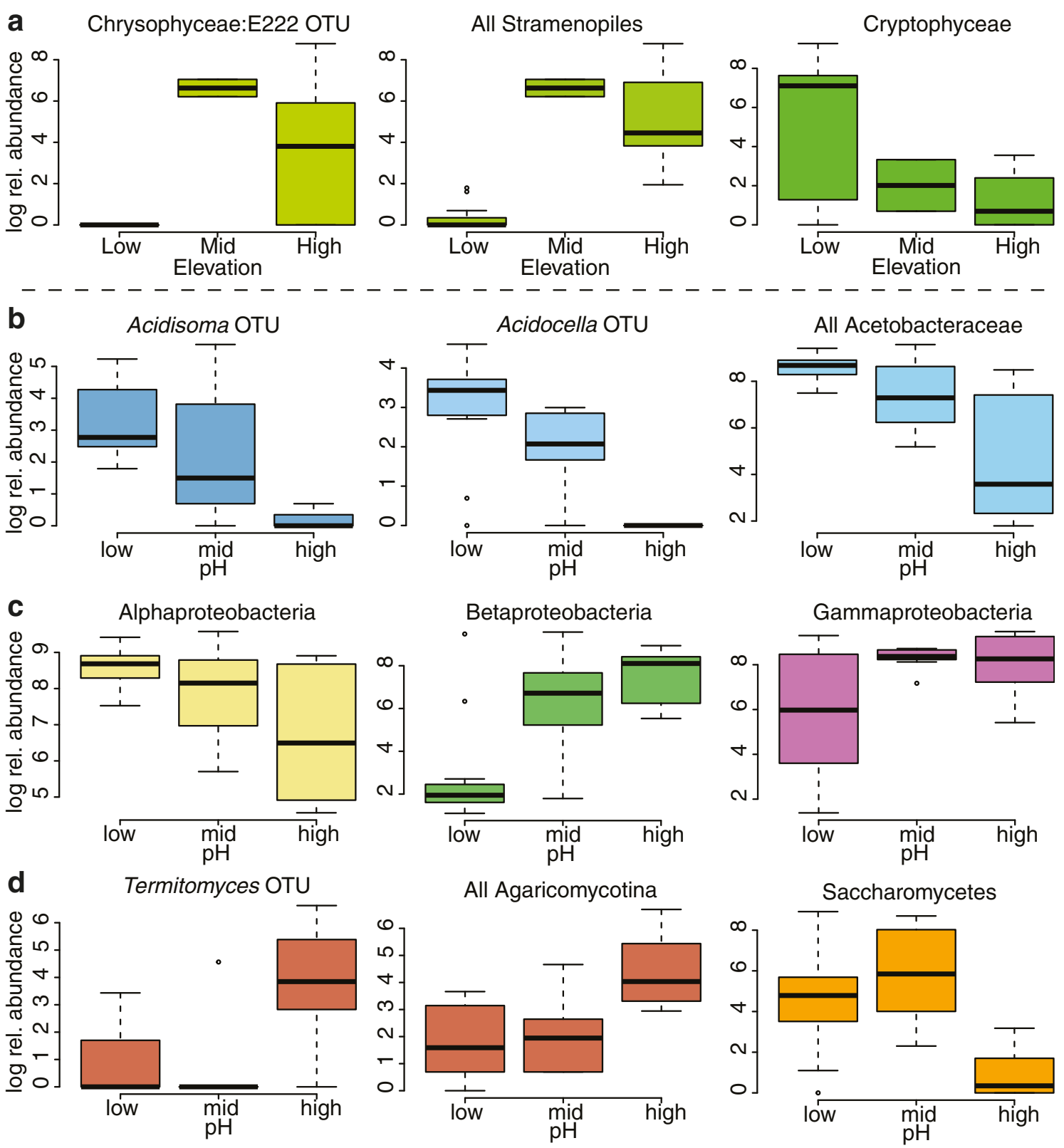

Fig. 3 Boxplots showing results of ANCOM analysis by elevation (a) and $\mathrm{pH}(\mathbf{b}-\mathbf{d})$. Elevation categories are low (400-600 m a.s.1.), mid (600$900 \mathrm{~m}$ a.s.1.), and high (>900 $\mathrm{m}$ a.s.1.). We acknowledge that mid elevation is under-sampled (three pitchers) and is included here for illustrative purposes despite not being strictly statistically comparable to the other two categories. $\mathrm{pH}$ categories are low $(\leq 3.0)$, mid (3.0-4.5), and high $(\geq 5.0)$. In (a), we compared the one significantly differentially

larvae and non-ant insect prey exhibit no significant trends in abundance; however, there was a slight increasing trend for the latter (Poisson regression, $z$ value $=1.972, p=0.049$ ).

Abundances of culicids, brachyceran larvae, ants, other insect prey, and mites all decreased with increasing $\mathrm{pH}$ (Table 5; culicids, mites, ants, other insects: $p<0.001$; brachyceran larvae, $p=0.002$ ). The abundances of culicids, ceratopogonids, and mites all significantly increase with canopy openness (Table 5; $p<0.001$ for culicids and mites, $p=$

abundant OTU to the larger taxon to which it belongs and contrast it to an ecologically comparable taxon, Cryptophyceae. In (b), we compared the two significantly differentially abundant OTUs to the family to which they belong, as well as their class contrasted against two other Proteobacterial classes (c). In (d), we compared the one significantly differentially abundant OTU to the class to which they belong, and contrasted the pattern against another fungal class

0.002 for ceratopogonids), whereas ants decrease with increasing canopy openness (Table $5, p<0.001$ ).

\section{Discussion}

Bacterial and eukaryotic communities inhabiting the same Nepenthes mindanaoensis pitchers change with elevation in different ways. Bacterial community composition was 


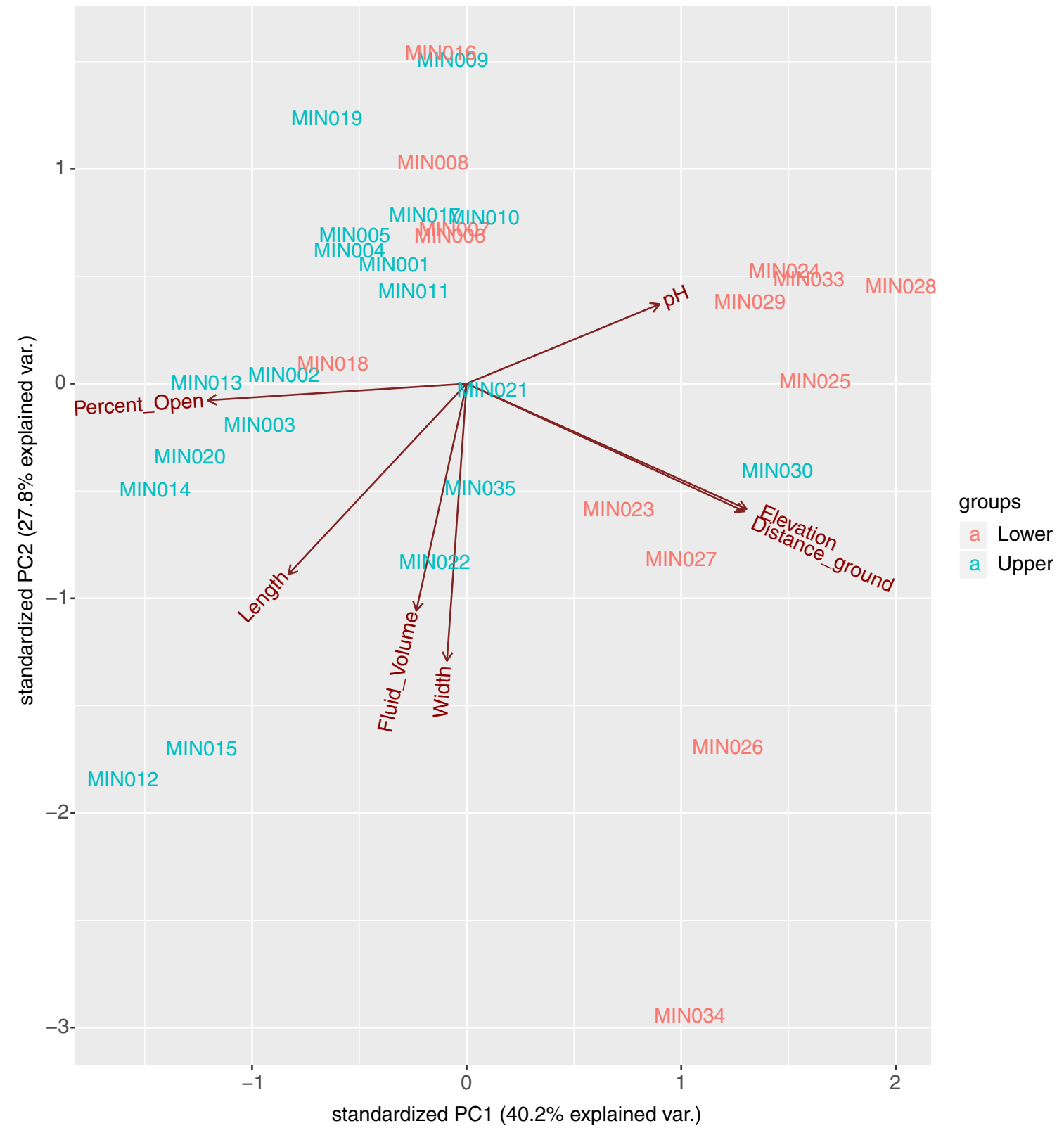

Fig. 4 Principle components analysis (PCA) plot showing axes of variation for the metadata of all sampled pitchers: elevation ( $\mathrm{m}$ a.s.l.), ground (Euclidian) distance (m), $\mathrm{pH}$ level, the amount of open sky above from the perspective of the pitcher ("Percent Open," i.e., canopy

much more strongly influenced by $\mathrm{pH}$ than by elevation, while elevation had the greatest effect on eukaryotic community composition. Moreover, when numerically dominant metazoan sequence data are removed from the eukaryote OTU table, non-metazoan eukaryotes are still strongly impacted by elevation in our study: the trend is not strictly driven by the macroscopic/multicellular members. This difference between the two domains could be due to the stark physiological differences between them, such as the greater metabolic diversity of bacteria, which grants them wider niche breadth [42]. openness), the length and width of the pitcher ( $\mathrm{mm})$, and the volume of the fluid sample $(\mathrm{mL})$. Points are labeled with the sample ID and colored by pitcher morph: "lower pitchers" in red and "upper pitchers" in blue

Elevation and Euclidian distance covary in our study, preventing the separation of elevational effects from potential effects of spatial distance; however, there is evidence suggesting that spatial distance plays little role in pitcher community composition. First, we do not find a distance-decay pattern for either bacteria or eukaryotes, suggesting that neither group is dispersal-limited within our transect [81, 82]. Second, despite greater distances between pitchers at high elevation in the transect, they do not differ in the degree of pitcher-to-pitcher turnover compared to the low elevation pitchers. This demonstrates that community composition is fairly stable within 
Table 4 Results of tests on relationships between insect morphospecies/ order-level richness (based on counts of physical specimens) and the other examined factors. All factors were included in a single generalized linear model for each individual arthropod category (ant morphospecies, culicid morphospecies, and prey insect orders not including ants), using a Poisson regression

\begin{tabular}{|c|c|c|c|c|c|c|}
\hline \multirow[t]{2}{*}{ Factor } & \multicolumn{2}{|c|}{ Culicid morphospecies } & \multicolumn{2}{|c|}{ Ant morphospecies } & \multicolumn{2}{|c|}{ Non-ant prey orders } \\
\hline & $z$ value & $p$ value & $z$ value & $p$ value & $z$ value & $p$ value \\
\hline Elevation & -1.253 & 0.210 & 1.234 & 0.217 & 0.349 & 0.727 \\
\hline $\mathrm{pH}$ & -2.890 & $0.004 *$ & -1.933 & 0.053 & -0.878 & 0.380 \\
\hline Canopy openness & 0.030 & 0.976 & -1.706 & 0.088 & -1.172 & 0.241 \\
\hline Fluid volume & 2.030 & 0.042 & 0.535 & 0.593 & -0.696 & 0.486 \\
\hline Pitcher length & -1.714 & 0.086 & -1.784 & 0.074 & -0.235 & 0.814 \\
\hline Pitcher morph (uppers relative to lowers) & 0.401 & 0.688 & 0.116 & 0.908 & -0.550 & 0.583 \\
\hline Pitcher color (red relative to green) & 0.251 & 0.802 & 0.188 & 0.851 & -2.044 & 0.041 \\
\hline
\end{tabular}

*Significant at a Bonferroni-corrected alpha level of 0.0167

elevation categories, although different between them. The fairly small total geographic distance of our transect $(\sim$ $4.2 \mathrm{~km}$ ) may effectively reduce any effect of physical distance that could potentially shape community structure at larger scales. Nevertheless, we found biologically meaningful patterns that are consistent with effects of elevation found in other studies.

In support of previous findings, we generally see arthropod abundances decreasing with increasing elevation. This has been documented for aquatic insects [91], mites [92], and ants [93]; and corresponds with changes in temperature and precipitation gradients. The notable exception here is that abundance of non-ant insect prey items slightly increases with elevation (Table 5) - possibly a better reflection of the biology of prey capture rather than that of the relative abundances of the insects themselves (Supplementary Discussion). While eukaryotic community composition and the abundances of individual members (whether sequence-based or specimenbased) change with elevation, alpha diversity (i.e., morphospecies richness or effective number of species sensu Jost [70]) does not significantly change with elevation for any of our higher taxa, including bacteria, micro-eukaryotes, and
Table 5 Results of tests on relationships between arthropod abundance (counts of physical specimens) and all examined factors. All factors were included in a single generalized linear model (along with elevation) for each individual arthropod category (culicids, ceratopogonids, brachyceran larvae, mites, ants, and other insects), using a Poisson regression

\begin{tabular}{|c|c|c|c|c|c|c|}
\hline \multirow{2}{*}{$\begin{array}{l}\text { Likely Inquilines } \\
\text { Factor }\end{array}$} & \multicolumn{2}{|c|}{ Culicids $(n=722)$} & \multicolumn{2}{|c|}{ Ceratopogonids $(n=69)$} & \multicolumn{2}{|c|}{ Brachyceran larvae $(n=13)$} \\
\hline & $z$ value & $p$ value & $z$ value & $p$ value & $z$ value & $p$ value \\
\hline Elevation & -5.236 & $1.65 \mathrm{E}-07 *$ & -1.853 & 0.064 & 1.419 & 0.156 \\
\hline $\mathrm{pH}$ & -12.329 & $2.00 \mathrm{E}-16^{*}$ & -2.057 & 0.040 & -3.166 & $0.002 *$ \\
\hline Canopy openness & 10.661 & $2.00 \mathrm{E}-16^{*}$ & 3.158 & $0.002 *$ & -1.317 & 0.188 \\
\hline Fluid volume & 14.559 & $2.00 \mathrm{E}-16^{*}$ & -1.421 & 0.155 & 0.715 & 0.475 \\
\hline Pitcher length & -13.491 & $2.00 \mathrm{E}-16^{*}$ & -6.373 & $1.86 \mathrm{E}-10 *$ & -0.646 & 0.518 \\
\hline Pitcher morph (Uppers relative to Lowers) & -0.356 & 0.722 & 2.533 & 0.011 & -1.206 & 0.228 \\
\hline Pitcher color (Red relative to Green) & -0.906 & 0.365 & 4.091 & $4.30 \mathrm{E}-05^{*}$ & -2.015 & 0.044 \\
\hline Likely prey & \multicolumn{2}{|c|}{ Mites $(n=87)$} & \multicolumn{2}{|c|}{ Ants $(n=1172)$} & \multicolumn{2}{|c|}{ Other insects $(n=122)$} \\
\hline Factor & $z$ value & $p$ value & $z$ value & $p$ value & $z$ value & $p$ value \\
\hline Elevation & -4.141 & $3.46 \mathrm{E}-05^{*}$ & -18.349 & $2.00 \mathrm{E}-16^{*}$ & 1.972 & 0.049 \\
\hline $\mathrm{pH}$ & -3.624 & $2.90 \mathrm{E}-04 *$ & -4.244 & $2.19 \mathrm{E}-05^{*}$ & -4.148 & $3.36 \mathrm{E}-05^{*}$ \\
\hline Canopy openness & 3.284 & $0.001 *$ & -16.015 & $2.00 \mathrm{E}-16^{*}$ & -1.592 & 0.111 \\
\hline Fluid volume & 3.219 & $0.001 *$ & -10.619 & $2.00 \mathrm{E}-16^{*}$ & -0.201 & 0.841 \\
\hline Pitcher length & -2.539 & 0.011 & 6.928 & $4.25 \mathrm{E}-12 *$ & -1.622 & 0.105 \\
\hline Pitcher morph (uppers relative to lowers) & -6.109 & $1.00 \mathrm{E}-09 *$ & 3.278 & $0.001^{*}$ & -0.883 & 0.377 \\
\hline Pitcher color (red relative to green) & -0.245 & 0.806 & -7.363 & $1.80 \mathrm{E}-13 *$ & -2.608 & 0.009 \\
\hline
\end{tabular}

*Significant at a Bonferroni-corrected alpha level of 0.008 
arthropods. Elevation may have a smaller effect on richness in our study system because Nepenthes phytotelm communities are comprised of specialized members and have a relatively small potential species pool compared to other environmental DNA samples [65].

A particularly striking change in the eukaryotic taxonomic composition is that Cryptophyceae seems to be replaced by Stramenopiles (primarily Chrysophyceae) at high elevation (Fig. 3a). Past studies of algal communities in high-altitude lakes, using either molecular or morphological methods, found Chrysophyceae to be the most important members of those communities, and Cryptophyceae were relatively less important both in terms of richness and abundance [37, 92-94]. In contrast, Cryptophyceae are more common and diverse elsewhere [18, 95]. Grossman et al. [37] suggested that Chrysophyceae function as an indicator taxon because they reflect the general response of aquatic protist communities to elevational gradients. That phytotelmata such as pitchers can reflect the macroecology of freshwater lakes is intriguing. Tolotti et al. [93] show that Chrysophyceae thrive in high-altitude lakes because they are well-adapted to the oligotrophic conditions common in such lakes. In our study, the abundance of ants, which are the pitchers' main insect prey, significantly decreases with elevation. It is thus quite possible that the fluid in pitchers at high elevation is less nutrient-rich than low elevation pitchers due to the scarcity of prey in the fluid.

Differences in light requirements could also influence algal patterns [96]. Canopy openness has a significant correlation with elevation in our study, as pitchers grew in more shaded microenvironments at higher elevations. However, canopy openness does not necessarily explain the influence of elevation overall. While some responses are concordant between elevation and canopy (i.e., culicid, ceratopogonid, and mite abundance, Table 5), others are not (i.e., ant abundance, Table 5), possibly reflecting individual ecological differences (Supplementary Discussion).

The plant-regulated trait with the strongest effects in our study was $\mathrm{pH}$. Nepenthes mindanaoensis exhibits a wide $\mathrm{pH}$ range: samples measured from 6.5 down to the very acidic $\mathrm{pH}$ 1.5. This matches previous observations that the Nepenthes species with the lowest $\mathrm{pH}$ levels also tend to have the greatest $\mathrm{pH}$ variance [59]. Fluid $\mathrm{pH}$ is the only measured factor with significant effects on bacterial community composition, and it also influences eukaryotic community composition, though to a lesser degree than does elevation. The strong response of bacteria to $\mathrm{pH}$ fits with the well-known narrow $\mathrm{pH}$ requirements of bacteria [97]. Higher $\mathrm{pH}$ levels may require fewer adaptations, thus allowing for greater diversity. This is reflected by the higher $16 \mathrm{~S}$-based bacterial alpha diversity at higher $\mathrm{pH}$ levels in our study. OTU-based relative abundance analysis verifies this, as the characteristically acidophilic family Acetobacteraceae [98] dominates at low $\mathrm{pH}$, particularly
Acidocella (Fig. 2), making up as much as $99.8 \%$ of bacterial sequences within a given fluid sample.

In contrast with most bacterial groups, but similar to Acetobacteraceae, we found that abundances of all arthropod groups tend to increase with decreasing $\mathrm{pH}$. Dipteran inquilines are likely to be specially adapted to the pitcher digestive fluid environment. For example, many pitcher-associated larvae are specialized [59], including Tripteroides where all described Nepenthes-associated species have an obligate association [99]. However, it is still somewhat surprising that not only the abundance but also the richness of culicids increases with decreasing $\mathrm{pH}$. This suggests that all four culicid morphospecies are equally tolerant of acidic conditions, rather than the existence of multiple species with different physiological tolerances that only co-occur in more moderate conditions. Prey capture induces fluid acidification [100, 101], and an increase in nutrient availability could explain the relationship between high abundance of ants, other insect prey, and mites with low $\mathrm{pH}$.

For over a century, ecologists have studied elevational patterns of biodiversity in plants and animals, yet only in the past decade have microbes received similar scrutiny. The extent to which microbes abide by the ecological laws of macrobes is still an open question. Few published studies of community changes across an elevational gradient have investigated phytotelmata [102-105], and none of these have compared microbes with macrobes. Aquatic microbial systems have also been understudied in macroecology relative to soil microbes [106], and protists are understudied relative to bacteria [18]. Thus, our work contributes to advancing knowledge of microbial macroecology in multiple ways, and has led to several novel insights. We find that high elevation Nepenthes algal communities are analogous to those of alpine lakes. Additionally, we have compared patterns of the living inquiline phytotelm community and their interactions with the external environment and the plant with those of the prey (Supplementary Discussion). Hence, our study provides insight into a wide range of taxa within a small aquatic ecosystem, both living and dead, and how they are affected by external conditions and plant-regulated traits. We can neither confirm nor deny that "everything is everywhere" à la Baas-Becking [7], as neither macrobes nor microbes (whether bacterial or eukaryotic) appear to be dispersal-limited across our transect. However, we can say that "the environment selects," but the key point is that different taxa experience the same environment differently. For arthropods and eukaryotic microbes (especially algae), the external environment of the elevational gradient is primarily what selects, whereas for bacteria it is the immediate chemical environment within the pitcher that primarily selects. Thus, in multi-taxon macroecology studies moving forward, it will be important to ask not merely "does the 
environment select?" but also "what is the relevant spatial scale of environmental factors for a given taxon?"

Acknowledgements The expedition was made possible by an Authority to Collect and Transport granted to PACB by the Philippine National Museum of Natural History (CPD-A-CT-2016-31). We thank Alma Mohagan for help with access to the site. We are grateful to Taylor Tai, Alden Dirks, and Elizabeth Benson for their assistance with extractions and to Corrie Moreau for help with ant identifications. We thank Alexandre Ponomarenko for help with ImageJ and Sangil Kim for help with the map. Finally, we thank Arvin Diesmos, Chris Baker, Sarah Maunsell, Richard Childers, David Haig, and Missy Holbrook for helpful discussions. KJG was supported by a Graduate Fellowship from the Department of Organismic and Evolutionary Biology, Harvard University and from the Putnam Expeditionary Fund, Museum of Comparative Zoology. LSB was funded by an NSF Graduate Fellowship, NSF Doctoral Dissertation Improvement Grant DEB1400982, and a James S. McDonnell Postdoctoral Fellowship. DJL was supported by NSF DEB-1541557. This project was supported by a grant from the National Geographic Society to NEP.

Data Availability Associated data including spreadsheets, R scripts, and Automontage photographs will be made available on Harvard Dataverse (https://doi.org/10.7910/DVN/JQHLAT). Raw sequence data is available in the NCBI Sequence Read Archive (https://www.ncbi.nlm.nih.gov/sra/ PRJNA607326).

Open Access This article is licensed under a Creative Commons Attribution 4.0 International License, which permits use, sharing, adaptation, distribution and reproduction in any medium or format, as long as you give appropriate credit to the original author(s) and the source, provide a link to the Creative Commons licence, and indicate if changes were made. The images or other third party material in this article are included in the article's Creative Commons licence, unless indicated otherwise in a credit line to the material. If material is not included in the article's Creative Commons licence and your intended use is not permitted by statutory regulation or exceeds the permitted use, you will need to obtain permission directly from the copyright holder. To view a copy of this licence, visit http://creativecommons.org/licenses/by/4.0/.

\section{References}

1. Rahbek C, Borregaard MK, Antonelli A, Colwell RK, Holt BG, Nogues-Bravo D, Rasmussen CMØ, Richardson K, Rosing MT, Whittaker RJ, Fjeldså J (2019) Building mountain biodiversity: geological and evolutionary processes. Science 365:1114-1119

2. Ohsawa M (1995) Latitudinal comparison of altitudinal changes in forest structure, leaf-type, and species richness in humid monsoon Asia. Global change and terrestrial ecosystems in monsoon Asia. Springer, pp 3-10

3. Janzen DH (1967) Why mountain passes are higher in the tropics. Am. Nat. 101:233-249

4. Polato NR, Gill BA, Shah AA et al (2018) Narrow thermal tolerance and low dispersal drive higher speciation in tropical mountains. Proc. Natl. Acad. Sci. 115:12471-12476

5. Rahbek C (1995) The Elevational gradient of species richness: a uniform pattern? Ecography 18:200-205

6. Bryant JA, Lamanna C, Morlon $\mathrm{H}$ et al (2008) Colloquium paper: microbes on mountainsides: contrasting elevational patterns of bacterial and plant diversity. Proc. Natl. Acad. Sci. U. S. A. 105(Suppl 1):11505-11511. https://doi.org/10.1073/pnas. 0801920105
7. O'Malley MA (2008) "Everything is everywhere: but the environment selects": ubiquitous distribution and ecological determinism in microbial biogeography. Studies in History and Philosophy of Science Part C: Studies in History and Philosophy of Biological and Biomedical Sciences 39:314-325

8. Yuan Y, Si G, Wang J, Luo T, Zhang G (2014) Bacterial community in alpine grasslands along an altitudinal gradient on the Tibetan Plateau. FEMS Microbiol. Ecol. 87:121-132

9. Zhao Y, Song C, Dong $\mathrm{H}$ et al (2018) Community structure and distribution of culturable bacteria in soil along an altitudinal gradient of Tianshan Mountains, China. Biotechnology \& Biotechnological Equipment 32:397-407

10. Debnath R, Yadav A, Gupta VK et al (2016) Rhizospheric bacterial community of endemic Rhododendron arboreum Sm. Ssp. delavayi along eastern Himalayan slope in Tawang. Frontiers in. Plant Sci. 7:1345

11. Shen C, Xiong J, Zhang H et al (2013) Soil pH drives the spatial distribution of bacterial communities along elevation on Changbai Mountain. Soil Biol. Biochem. 57:204-211

12. Wang J-T, Cao P, Hu H-W et al (2015) Altitudinal distribution patterns of soil bacterial and archaeal communities along Mt. Shegyla on the Tibetan plateau. Microb. Ecol. 69:135-145

13. Staley JT, Gosink JJ (1999) Poles apart: biodiversity and biogeography of sea ice bacteria. Annu. Rev. Microbiol. 53:189-215

14. Qvit-Raz N, Finkel OM, Al-Deeb TM et al (2012) Biogeographical diversity of leaf-associated microbial communities from salt-secreting Tamarix trees of the Dead Sea region. Res. Microbiol. 163:142-150. https://doi.org/10.1016/j.resmic.2011. 11.006

15. Cho JC, Tiedje JM (2000) Biogeography and degree of endemicity of fluorescent Pseudomonas strains in soil. Appl. Environ. Microbiol. 66:5448-5456

16. Horner-Devine MC, Lage M, Hughes JB, Bohannan BJ (2004) A taxa-area relationship for bacteria. Nature 432:750

17. Fenchel T (2003) Biogeography for bacteria. Science 301:925926

18. Boenigk J, Wodniok S, Bock C et al (2018) Geographic distance and mountain ranges structure freshwater protist communities on a European scale. Metabarcoding and Metagenomics 2:e21519

19. Soininen J (2012) Macroecology of unicellular organisms-patterns and processes. Environ. Microbiol. Rep. 4:10-22

20. Zhang B, Liang C, He H, Zhang X (2013) Variations in soil microbial communities and residues along an altitude gradient on the northern slope of Changbai Mountain, China. PLoS One 8:e66184

21. Fierer N, McCain CM, Meir P, Zimmermann M, Rapp JM, Silman MR, Knight R (2011) Microbes do not follow the elevational diversity patterns of plants and animals. Ecology 92:797-804

22. Nottingham AT, Fierer N, Turner BL, Whitaker J, Ostle NJ, McNamara N, Bardgett RD, Leff JW, Salinas N, Silman MR, Kruuk LEB, Meir P (2018) Microbes follow Humboldt: temperature drives plant and soil microbial diversity patterns from the Amazon to the Andes. Ecology 99:2455-2466

23. Li H, Zeng J, Ren L et al (2017) Contrasting patterns of diversity of abundant and rare bacterioplankton in freshwater lakes along an elevation gradient. Limnol. Oceanogr. 62:1570-1585

24. Zeng J, Zhao D, Li H, Huang R, Wang J, Wu QL (2016) A monotonically declining elevational pattern of bacterial diversity in freshwater lake sediments. Environ. Microbiol. 18:5175-5186

25. Wang J, Soininen J, Zhang Y et al (2011) Contrasting patterns in elevational diversity between microorganisms and macroorganisms. J. Biogeogr. 38:595-603

26. Wang J, Soininen J, Zhang Y et al (2012) Patterns of elevational beta diversity in micro-and macroorganisms. Glob. Ecol. Biogeogr. 21:743-750 
27. Yang H, Lü G, Jiang H et al (2017) Diversity and distribution of soil micro-fungi along an elevation gradient on the north slope of Changbai Mountain. J. For. Res. 28:831-839

28. Liu L, Hart MM, Zhang J et al (2015) Altitudinal distribution patterns of AM fungal assemblages in a Tibetan alpine grassland. FEMS Microbiol. Ecol. 91

29. Ni Y, Yang T, Zhang $\mathrm{K}$ et al (2018) Fungal communities along a small-scale elevational gradient in an alpine tundra are determined by soil carbon nitrogen ratios. Front. Microbiol. 9:1815

30. Yang T, Weisenhorn P, Gilbert JA, Ni Y, Sun R, Shi Y, Chu H (2016) Carbon constrains fungal endophyte assemblages along the timberline. Environ. Microbiol. 18:2455-2469

31. Bahram M, Põlme S, Kõljalg U, Zarre S, Tedersoo L (2012) Regional and local patterns of ectomycorrhizal fungal diversity and community structure along an altitudinal gradient in the Hyrcanian forests of northern Iran. New Phytol. 193:465-473

32. Coince A, Cordier T, Lengellé J et al (2014) Leaf and rootassociated fungal assemblages do not follow similar elevational diversity patterns. PLoS One 9:e100668

33. Schön ME, Nieselt K, Garnica S (2018) Belowground fungal community diversity and composition associated with Norway spruce along an altitudinal gradient. PLoS One 13:e0208493

34. Qian X, Chen L, Guo X et al (2018) Shifts in community composition and co-occurrence patterns of phyllosphere fungi inhabiting Mussaenda shikokiana along an elevation gradient. Peer J 6:e5767

35. Pinto-Figueroa EA, Seddon E, Yashiro E et al (2019) Archaeorhizomycetes spatial distribution in soils along wide elevational and environmental gradients reveal co-abundance patterns with other fungal saprobes and potential weathering capacities. Front. Microbiol. 10:656

36. Teittinen A, Kallajoki L, Meier S et al (2016) The roles of elevation and local environmental factors as drivers of diatom diversity in subarctic streams. Freshw. Biol. 61:1509-1521

37. Grossmann L, Jensen M, Pandey RV et al (2016) Molecular investigation of protistan diversity along an elevation transect of alpine lakes. Aquat. Microb. Ecol. 78:25-37

38. He F, Dong X, Sun M, Cai Q (2015) Altitudinal pattern of stream periphyton biomass in tributaries of the Lancang-Mekong River: an indicator of anthropogenic impact? Quat. Int. 380:282-287

39. Seppey CV, Broennimann O, Buri A et al (2019) Soil protist diversity in the Swiss western Alps is better predicted by topoclimatic than by edaphic variables. J. Biogeogr. 00:1-13. https:// doi.org/10.1111/jbi.13755

40. Shen C, Liang W, Shi Y et al (2014) Contrasting elevational diversity patterns between eukaryotic soil microbes and plants. Ecology 95:3190-3202

41. Cohen Y, Pasternak Z, Johnke J, Abed-Rabbo A, Kushmaro A, Chatzinotas A, Jurkevitch E (2019) Bacteria and microeukaryotes are differentially segregated in sympatric wastewater microhabitats. Environ. Microbiol. 21:1757-1770

42. Wu W, Lu H-P, Sastri A et al (2018) Contrasting the relative importance of species sorting and dispersal limitation in shaping marine bacterial versus protist communities. The ISME Journal 12:485

43. Liu L, Yang J, Lv H, Yu X, Wilkinson DM, Yang J (2015) Phytoplankton communities exhibit a stronger response to environmental changes than bacterioplankton in three subtropical reservoirs. Environmental Science \& Technology 49:10850-10858

44. Ragon M, Fontaine M, Moreira D, López-García P (2012) Different biogeographic patterns of prokaryotes and microbial eukaryotes in epilithic biofilms. Mol. Ecol. 21:3852-3868

45. Soininen J, Korhonen JJ, Karhu J, Vetterli A (2011) Disentangling the spatial patterns in community composition of prokaryotic and eukaryotic lake plankton. Limnol. Oceanogr. 56:508-520

46. Xu G, Lin Y, Zhang S et al (2017) Shifting mechanisms of elevational diversity and biomass patterns in soil invertebrates at treeline. Soil Biol. Biochem. 113:80-88
47. Kitching R (2001) Food webs in phytotelmata: "bottom-up" and "top-down" explanations for community structure. Annu. Rev. Entomol. 46:729-760

48. Baker CC, Bittleston LS, Sanders JG, Pierce NE (2016) Dissecting host-associated communities with DNA barcodes. Phil Trans R Soc B 371:20150328

49. Adlassnig W, Peroutka M, Lendl T (2011) Traps of carnivorous pitcher plants as a habitat: composition of the fluid, biodiversity and mutualistic activities. Ann. Bot. 107:181-194. https://doi.org/ 10.1093/aob/mcq238

50. Juniper BE, Robins RJ, Joel DM (1989) The carnivorous plants. London, etc.: academic press

51. McPherson S, Robinson A, Fleischmann A (2009) Pitcher plants of the Old World. Redfern Natural History Productions Dorset

52. Gilbert KJ, Nitta JH, Talavera G, Pierce NE (2018) Keeping an eye on coloration: ecological correlates of the evolution of pitcher traits in the genus Nepenthes (Caryophyllales). Biol. J. Linn. Soc. 123:321-327

53. Schaefer HM, Ruxton GD (2008) Fatal attraction: carnivorous plants roll out the red carpet to lure insects. Biol. Lett. 4:153155. https://doi.org/10.1098/rsbl.2007.0607

54. Moran JA (1996) Pitcher dimorphism, prey composition and the mechanisms of prey attraction in the pitcher plant Nepenthes rafflesiana in Borneo. J. Ecol.:515-525

55. Gaume L, Bazile V, Huguin M, Bonhomme V (2016) Different pitcher shapes and trapping syndromes explain resource partitioning in Nepenthes species. Ecology and Evolution 6:1378-1392

56. Clarke C (1997) The effects of pitcher dimorphism on the metazoan community of the carnivorous plant Nepenthes bicalcarata Hook. f. the Malayan Nature Journal (Malaysia)

57. Ratsirarson J, Silander Jr JA (1996) Structure and dynamics in Nepenthes madagascariensis pitcher plant micro-communities. Biotropica:218-227

58. Moran JA, Hawkins BJ, Gowen BE, Robbins SL (2010) Ion fluxes across the pitcher walls of three Bornean Nepenthes pitcher plant species: flux rates and gland distribution patterns reflect nitrogen sequestration strategies. J. Exp. Bot. 61:1365-1374

59. Bittleston L (2018) Commensals of Nepenthes pitchers. Carnivorous plants: physiology, ecology, and evolution. Oxford University press. https://doi.org/10.1093/oso/ 9780198779841.00323 :

60. Hua Y, Li H (2005) Food web and fluid in pitchers of Nepenthes mirabilis in Zhuhai, China. Acta Botanica Gallica 152:165-175

61. Malkmus R, Dehling JM (2008) Anuran amphibians of Borneo as phytotelm-breeders - a synopsis. Herpetozoa 20:165-172

62. Lim K, Ng P (1991) Nepenthiphilous larvae and breeding habits of the sticky frog, Kalophrynus pleurostigma Tschudi (Amphibia: Microhylidae). Raffles Bulletin of Zoology 39:209-214

63. Das I, Haas A (2010) New species of Microhyla from Sarawak: Old World's smallest frogs crawl out of miniature pitcher plants on Borneo (Amphibia: Anura: Microhylidae). Zootaxa 2571:37-52

64. Tan H, Ng P (2008) First record in Singapore of a nepenthiphilous crab, Geosesarma perracae (Crustacea: Decapoda: Sesarmidae). Nature in Singapore 1:201-205

65. Bittleston LS, Wolock CJ, Yahya BE et al (2018) Convergence between the microcosms of Southeast Asian and North American pitcher plants. eLife 7:e36741

66. Kanokratana P, Mhuanthong W, Laothanachareon T, Tangphatsornruang S, Eurwilaichitr L, Kruetreepradit T, Mayes S, Champreda V (2016) Comparative study of bacterial communities in Nepenthes. Microb. Ecol. 72:381-393

67. Soininen J, Lennon JJ, Hillebrand H (2007) A multivariate analysis of beta diversity across organisms and environments. Ecology 88:2830-2838 
68. Brown RM, Siler CD, Oliveros CH et al (2013) Evolutionary processes of diversification in a model island archipelago. Annu. Rev. Ecol. Evol. Syst. 44:411-435

69. Amoroso VB, Lagunday NE, Coritico FP, Colong RD (2017) Nepenthes alfredoi (Caryophyllales, Nepenthaceae), a new species of pitcher plant from Mindanao, Philippines. Philippine Journal of Systematic Biology 11:14-19

70. Gronemeyer T, Suarez W, Nuytemans H et al (2016) Two new Nepenthes species from the Philippines and an emended description of Nepenthes ramos. Plants 5:23

71. Fick SE, Hijmans RJ (2017) WorldClim 2: new 1-km spatial resolution climate surfaces for global land areas. Int. J. Climatol. 37: $4302-4315$

72. RCoreTeam (2013) R: A Language and environment for statistical computing. 55:275-286

73. Rasband W (2012) ImageJ: image processing and analysis in Java. Astrophysics Source Code Library

74. General DM, Alpert GD (2012) A synoptic review of the ant genera (Hymenoptera, Formicidae) of the Philippines. Zookeys: 1-111. https://doi.org/10.3897/zookeys.200.2447

75. Rattanarithikul R (1982) A guide to the genera of mosquitoes (Diptera: Culicidae) of Thailand with illustrated keys, biological notes and preservation and mounting techniques. Mosq Syst 14:139-208

76. Sambrook J, Russell D (2001) Molecular cloning: a laboratory manual, the third edition

77. Caporaso JG, Lauber CL, Walters WA, Berg-Lyons D, Huntley J, Fierer N, Owens SM, Betley J, Fraser L, Bauer M, Gormley N, Gilbert JA, Smith G, Knight R (2012) Ultra-high-throughput microbial community analysis on the Illumina HiSeq and MiSeq platforms. ISME J 6:1621-1624. https://doi.org/10.1038/ismej. 2012.8

78. Caporaso JG, Lauber CL, Walters WA, Berg-Lyons D, Lozupone CA, Turnbaugh PJ, Fierer N, Knight R (2011) Global patterns of 16S rRNA diversity at a depth of millions of sequences per sample. Proc. Natl. Acad. Sci. U. S. A. 108(Suppl 1):4516-4522. https://doi.org/10.1073/pnas.1000080107

79. Stoeck T, Bass D, Nebel M et al (2010) Multiple marker parallel tag environmental DNA sequencing reveals a highly complex eukaryotic community in marine anoxic water. Mol. Ecol. 19(Suppl 1):21-31. https://doi.org/10.1111/j.1365-294X.2009.04480.x

80. Amaral-Zettler LA, McCliment EA, Ducklow HW, Huse SM (2009) A method for studying protistan diversity using massively parallel sequencing of V9 hypervariable regions of small-subunit ribosomal RNA genes. PLoS One 4:e6372. https://doi.org/10. 1371/journal.pone.0006372

81. Nekola JC, White PS (1999) The distance decay of similarity in biogeography and ecology. J. Biogeogr. 26:867-878

82. Wetzel CE, de Bicudo DC, Ector L et al (2012) Distance decay of similarity in neotropical diatom communities. PLoS One 7: e45071

83. Oksanen J, Blanchet FG, Kindt R, et al. (2013) Package "vegan." Community ecology package, version 2 :

84. Jost L (2006) Entropy and diversity. Oikos 113:363-375

85. Mandal S, Van Treuren W, White RA et al (2015) Analysis of composition of microbiomes: a novel method for studying microbial composition. Microb. Ecol. Health Dis. 26:27663

86. Bittleston LS, Baker C, Strominger LB et al (2016) Metabarcoding as a tool for investigating arthropod diversity in Nepenthes pitcher plants. Austral Ecology 41:120-132

87. Fashing NJ (2002) Nepenthacarus, a new genus of Histiostomatidae (Acari: Astigmata) inhabiting the pitchers of Nepenthes mirabilis (Lour.) Druce in far North Queensland, Australia. Aust. J. Entomol. 41:7-17

88. Lam W, Ling J, Lum T, Tan H (2020) Ecology and natural history of swimming pitcher mites (Creutzeria spp., Histiostomatidae) from the traps of Nepenthes pitcher plants. J. Zool. 310:1-9
89. Madsen PB, Morabowen A, Andino P et al (2015) Altitudinal distribution limits of aquatic macroinvertebrates: an experimental test in a tropical alpine stream. Ecological Entomology 40:629-638

90. Marian F, Sandmann D, Krashevska V et al (2018) Altitude and decomposition stage rather than litter origin structure soil microarthropod communities in tropical montane rainforests. Soil Biol. Biochem. 125:263-274

91. Szewczyk T, McCain CM (2016) A systematic review of global drivers of ant elevational diversity. PLoS One 11:e0155404

92. Tolotti M, Manca M, Angeli N et al (2006) Phytoplankton and zooplankton associations in a set of Alpine high altitude lakes: geographic distribution and ecology. Hydrobiologia 562:99-122

93. Tolotti M, Thies H, Cantonati M et al (2003) Flagellate algae (Chrysophyceae, Dinophyceae, Cryptophyceae) in 48 high mountain lakes of the northern and southern slope of the eastern Alps: biodiversity, taxa distribution and their driving variables. Hydrobiologia 502:331-348

94. Triadó-Margarit X, Casamayor EO (2012) Genetic diversity of planktonic eukaryotes in high mountain lakes (Central Pyrenees, Spain). Environ. Microbiol. 14:2445-2456. https://doi.org/10. 1111/j.1462-2920.2012.02797.x

95. Debroas D, Domaizon I, Humbert J-F, et al. (2017) Overview of freshwater microbial eukaryotes diversity: a first analysis of publicly available metabarcoding data. FEMS Microbiology Ecology 93:fix023

96. Charvet S, Vincent WF, Lovejoy C (2014) Effects of light and prey availability on Arctic freshwater protist communities examined by high-throughput DNA and RNA sequencing. FEMS Microbiol. Ecol. 88:550-564

97. Rabotnova IL (1963) The importance of physical-chemical factors ( $\mathrm{pH}$ and $\mathrm{rH} 2$ ) for the life activity of microorganisms. Army Biological Labs Frederick, MD

98. Komagata K, Iino T, Yamada Y (2014) The family Acetobacteraceae. The Prokaryotes: Alphaproteobacteria and Betaproteobacteria 3-78

99. Belkin JN (1955) The Tripteroides caledonica complex of mosquitoes in Melanesia (Diptera: Culicidae). University of Hawai'i Press

100. Saganová M, Bokor B, Stolárik T, Pavlovič A (2018) Regulation of enzyme activities in carnivorous pitcher plants of the genus Nepenthes. Planta:1-14

101. Lloyd FE (2011) The carnivorous plants. Read Books Ltd

102. Busse A, Schoreisz JJ, Petermann JS (2019) Predators and priority effects suggested as potential drivers of microfauna communities in a community transplantation experiment along an elevational gradient. Oikos 128:929-942

103. Richardson BA, Richardson M, Scatena F, McDowell WH (2000) Effects of nutrient availability and other elevational changes on bromeliad populations and their invertebrate communities in a humid tropical forest in Puerto Rico. J. Trop. Ecol. 16:167-188

104. Castaño-Meneses G (2016) Seasonal and altitude effects on the structure of arthropod communities associated with Tillandsia violacea Baker (Bromeliaceae) in a temperate forest of Mexico. Arthropod Plant Interact. 10:403-417

105. Sota T, Mogi M (1996) Species richness and altitudinal variation in the aquatic metazoan community in bamboo phytotelmata from North Sulawesi. Res. Popul. Ecol. 38:275-281

106. Wang J, Meier S, Soininen J et al (2017) Regional and global elevational patterns of microbial species richness and evenness. Ecography 40:393-402

Publisher's note Springer Nature remains neutral with regard to jurisdictional claims in published maps and institutional affiliations. 